\title{
Morphea in Saudi Arabia, a Clinical Study of 64 Patients
}

\author{
Ahmed Alhumidi ${ }^{1}$, Shaikhah Alanazi ${ }^{*}$ Mona Alfaraidi $^{3}$, Najd Alshamlan ${ }^{4}$, \\ Acya Alanazi ${ }^{5}$ and Raghad Khalil ${ }^{6}$ \\ ${ }^{1}$ Department of Pathology, College of medicine, King Saud University, Riyadh, Saudi Arabia \\ ${ }^{2}$ Department of Dermatology, Prince Sultan Military Medical City, Riyadh, Saudi Arabia \\ ${ }^{3}$ Department of Pathology, King Fahad Medical City, Riyadh, Saudi Arabia \\ ${ }^{4}$ Department of Pathology, King Faisal Specialist Hospital and Research Center, Riyadh, Saudi Arabia \\ ${ }^{5}$ Department of Languages and Translation, Princess Nourah bint Abdulrahman University, Riyadh, Saudi Arabia \\ ${ }^{6}$ Department of Biochemistry, King Abdullah International Medical Research Center, Riyadh, Saudi Arabia
}

Received: 13 September, 2017; Accepted: 22 September, 2017; Published: 02 October, 2017

*Corresponding author: Shaikhah Alanazi, MD, Department of Dermatology, Prince Sultan Military Medical City, Riyadh, Saudi Arabia, Tel: +966558686748; Fax: 0114980655; E-mail: shikahmd@hotmail.com

\begin{abstract}
Morphea is a cutaneous disorder characterized by excessive collagen deposition leading to thickening of the dermis, subcutaneous tissue or both. Clinically, it is classified into circumscribed, generalized including coalescent plaque and pansclerotic, linear, mixed and rarely guttate type. Morphea can present with laboratory abnormalities including positive antinuclear antibodies. Here we represent a clinical review of morphea in Saudi Arabia.
\end{abstract}

Keywords: Morphea; Scleroderma; Saudi Arabia;

\section{Introduction}

Morphea is a chronic idiopathic inflammatory disease characterized by excessive collagen deposition of the skin. It affects primarily the dermis and may extend to subcutaneous structures. Unlike systemic sclerosis, morphea lacks internal organ involvement. It may affect adults or children, and is slightly more common in females than males. Most previous studies have been performed in Caucasian patients, and few studies have investigated Asian populations. As of our knowledge, this is the first clinical study of morphea in Saudi population.

\section{Material and Methods}

We retrospectively reviewed 64 morphea cases that were diagnosed histologically 2006 to 2016 in King Khalid University Hospital, a tertiary hospital in Riyadh, Saudi Arabia. We went through each patient's medical record and retrieved data about gender, age, lesion body distribution, associated systemic diseases and serology. Morphea classified based on Laxer and Zulian's classification into circumscribed including superficial and deep, generalized including coalescent plaque and pansclerotic, linear, mixed and rarely guttate type. All the six cases that were not confirmed by histopathology were excluded from the study. Hence, the diagnosis of these morphea cases was based on the clinical presentation and histopathological features.

\section{Result}

Out of the 58 patients studied 34 (59\%) were females and $24(41 \%)$ were males (figure 1). Localized, linear and guttate morphea were the types observed in our study and their histological details were studied separately. Most of our cases were seen between 20-50 years of age group (table 1) with a mean of 36 and a standard deviation 15. Also, there is decrease in cases on both age extreme. Plaque localized morphea was seen in most of our patients (48 patients, 83\%) (figure 3,5). Linear morphea seen in three patients, two of them were females 19 and 27-year-old and one 23-year-old male (figure 4). Guttate type observed in only one patient, a 30-year-old male. Systemic Scleroderma diagnosed in six patients (figure 2).

Out of the 26 patients with serological tests, 13 patients (50\%) have ANA positive. Only three of those patients with positive ANA are sclerodermic, with age ranges between 8 and 45 years, all were females except one.

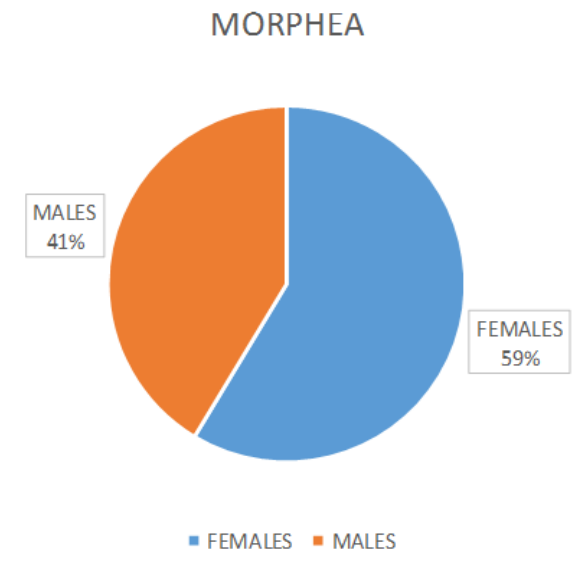

Figure 1: Females and males percentages 
Table 1: Patients data categorized based on gender, age, distribution and serology

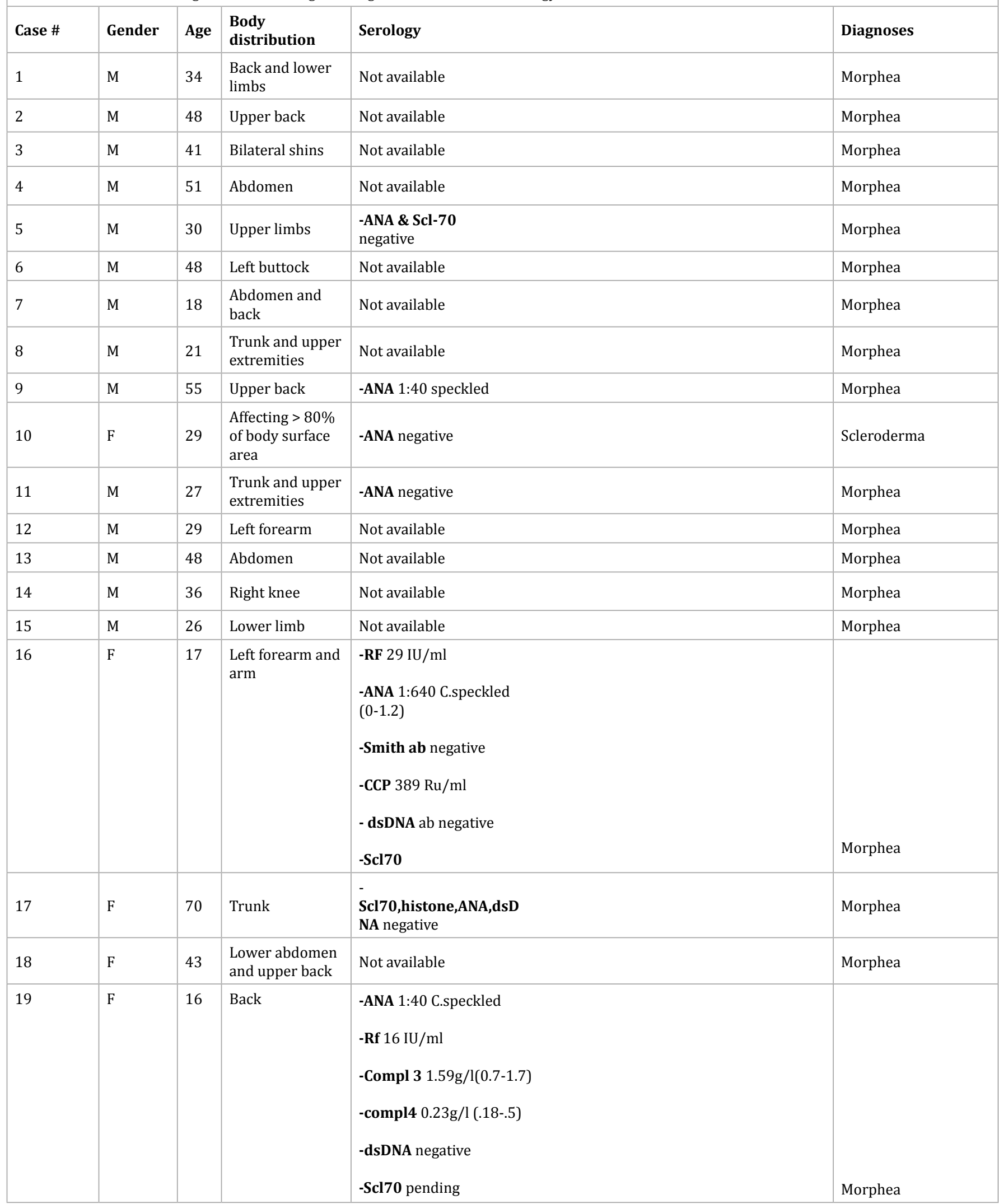




\begin{tabular}{|c|c|c|c|c|c|}
\hline 20 & $\mathrm{~F}$ & 51 & $\begin{array}{l}\text { Back and } \\
\text { Extremities }\end{array}$ & Not available & Morphea \\
\hline 21 & $\mathrm{~F}$ & 48 & Abdomen & -ANA,Scl70 negative & Morphea \\
\hline 22 & $\mathrm{~F}$ & 55 & Bilateral hands & Not available & Morphea \\
\hline 23 & M & 38 & Right arm & -ANA,Scl70 negative & Morphea \\
\hline 24 & M & 39 & Trunk \& thighs & Not available & Scleroderma \\
\hline 25 & $\mathrm{~F}$ & 8 & Abdomen & $\begin{array}{l}\text {-Scl70 21(0-20) } \\
\text {-RNP } 79.2(0-20) \\
\text {-ANA 1:80 DS (0-1.2) } \\
\text {-smith, SSA,SSB negative }\end{array}$ & Morphea \\
\hline 26 & $\mathrm{~F}$ & 22 & Trunk & Not available & Morphea \\
\hline 27 & $\mathrm{~F}$ & 30 & Abdomen & Not available & Morphea \\
\hline 28 & M & 61 & Upper back & Not available & Morphea \\
\hline 29 & $\mathrm{~F}$ & 53 & Right arm & $\begin{array}{l}-\mathbf{R F}<9.38 \\
\text {-ANA, dsDNA negative } \\
- \text { CRP } 20.6 \mathrm{mgs} / \mathrm{l}\end{array}$ & Morphea \\
\hline 30 & M & 31 & Lower limbs & $\begin{array}{l}\text {-ANCA 1:20 (0-1:40) } \\
\text {-ANA 1:40 F.S+nuclear (0-1.2) } \\
\text {-IgA 10.7g/l (0.9-4.5) } \\
\text {-dsDNA negative }\end{array}$ & Morphea \\
\hline 31 & $\mathrm{~F}$ & 50 & Right flank & Not available & Morphea \\
\hline 32 & $\mathrm{~F}$ & 39 & $\begin{array}{l}\text { Trunk and } \\
\text { abdomen }\end{array}$ & $\begin{array}{l}\text {-ANA 1:40 F speckled }(0-1.2) \\
\text {-RF negative }\end{array}$ & Morphea \\
\hline 33 & $\mathrm{~F}$ & 19 & Left lower limb & Not available & Morphea \\
\hline 34 & $\mathrm{~F}$ & 60 & Upper back & $-\mathbf{R F}$ negative & Morphea \\
\hline 35 & M & 19 & Scalp & Not available & Morphea \\
\hline 36 & M & 19 & Let flank & Not available & Morphea \\
\hline 37 & $\mathrm{~F}$ & 31 & $\begin{array}{l}\text { Left breast, left } \\
\text { thigh and left } \\
\text { forearm. }\end{array}$ & -RF , ANA,dsDNa, Scl70 negative & Morphea \\
\hline 38 & M & 38 & Left leg & Not available & Morphea \\
\hline 39 & $\mathrm{~F}$ & 32 & Left flank & -RF , ANA, dsDNa, Scl70 negative & Morphea \\
\hline 40 & $\mathrm{~F}$ & 41 & $\begin{array}{l}\text { Right hip and } \\
\text { buttocks }\end{array}$ & $\begin{array}{l}\text {-ANA 1:40 nuclear(0-1.2) } \\
\text {-Rf, CRP negative }\end{array}$ & Morphea \\
\hline 41 & $\mathrm{~F}$ & 27 & Scalp & -ANA 1:640 homogenous (0-1.2) & Morphea \\
\hline 42 & $\mathrm{~F}$ & 35 & Upper abdomen & -Ana, dsDNA negative & Morphea \\
\hline 43 & $\mathrm{~F}$ & 9 & Right Forearm & $\begin{array}{l}\text {-ANA 1:512 nuclear } \\
\text {-RNP, Scl70, dsDNA,SSA,SSB,Smith } \\
\text { ab,dermatomyositis, histone negative } \\
\text { - IgG,IgM,IgA,IgE normal limits }\end{array}$ & Scleroderma \\
\hline
\end{tabular}




\begin{tabular}{|c|c|c|c|c|c|}
\hline 44 & $\mathrm{~F}$ & 47 & Right arm & $\begin{array}{l}\text {-ANA 1:40 nuclear (0-1.2) } \\
\text {-Scl70, RF negative }\end{array}$ & Morphea \\
\hline 45 & $\mathrm{~F}$ & 37 & Right leg & Not available & Morphea \\
\hline 46 & $\mathrm{~F}$ & 73 & Upper chest & Not available & Morphea \\
\hline 47 & M & 22 & Right arm & Not available & Morphea \\
\hline 48 & M & 22 & Back & Not available & Morphea \\
\hline 49 & $\mathrm{~F}$ & 7 & Left upper arm & $\begin{array}{l}\text {-RF,ANA,Smith } \\
\text { ab,SSA,SSB,RNP,Scl70,dermatomyositis,dsDNa,Histone negative }\end{array}$ & Scleroderma \\
\hline 50 & $\mathrm{~F}$ & 23 & Abdomen & -ANA 1:40 nuclear & Morphea \\
\hline 51 & $\mathrm{~F}$ & 45 & Left arm & $\begin{array}{l}\text {-ANA 1:640 homogenous } \\
\text {-Scl70 62IU/ml (0-20) } \\
\text {-RNP } 99 \mathrm{IU} / \mathrm{ml}(0-20) \\
\text {-SSA } 117 \mathrm{IU} / \mathrm{ml}(0-20) \\
\text {-SSB } 40 \mathrm{IU} / \mathrm{ml}(0-20) \\
\text {-Smith ab,dsDNA ab negative }\end{array}$ & Scleroderma \\
\hline 52 & $\mathrm{~F}$ & 56 & Lower limbs & $\begin{array}{l}\text {-Anticardiolipin IgM } 7 \text { MPL/ML } \\
\text {-Anticardiolipin IgG } 32 \text { (6-12) GPL/ML } \\
\text {-RNP } 21 \\
(0-20) \\
\text {-Rf,ANA,dsDNA,SSA,SSB,Scl70 negative } \\
\text {-Anticardiolipin ab IgA negative } \\
\text {-Complement3 } 2.34 \mathrm{~g} / 1(0.7-1.7) \\
\text {-Complement4 } 0.57 \mathrm{~g} / 1(0.18-0.5)\end{array}$ & Morphea \\
\hline 53 & $\mathrm{~F}$ & 36 & Right shoulder & -ANA negative & Morphea \\
\hline 54 & $\mathrm{~F}$ & 42 & Left flank & $\begin{array}{l}\text {-ANA 1:280 homogenous (0-1.2) } \\
\text {-Rf } 16 \mathrm{IU} / \mathrm{ml}\end{array}$ & Scleroderma \\
\hline 55 & M & 23 & Legs and Arms & Not available & Morphea \\
\hline 56 & $\mathrm{~F}$ & 40 & Neck & Not available & Morphea \\
\hline 57 & $\mathrm{~F}$ & 30 & $\begin{array}{l}\text { Left leg and } \\
\text { bilateral arms }\end{array}$ & Not available & Morphea \\
\hline 58 & $\mathrm{~F}$ & 48 & Abdomen & Not available & Morphea \\
\hline
\end{tabular}




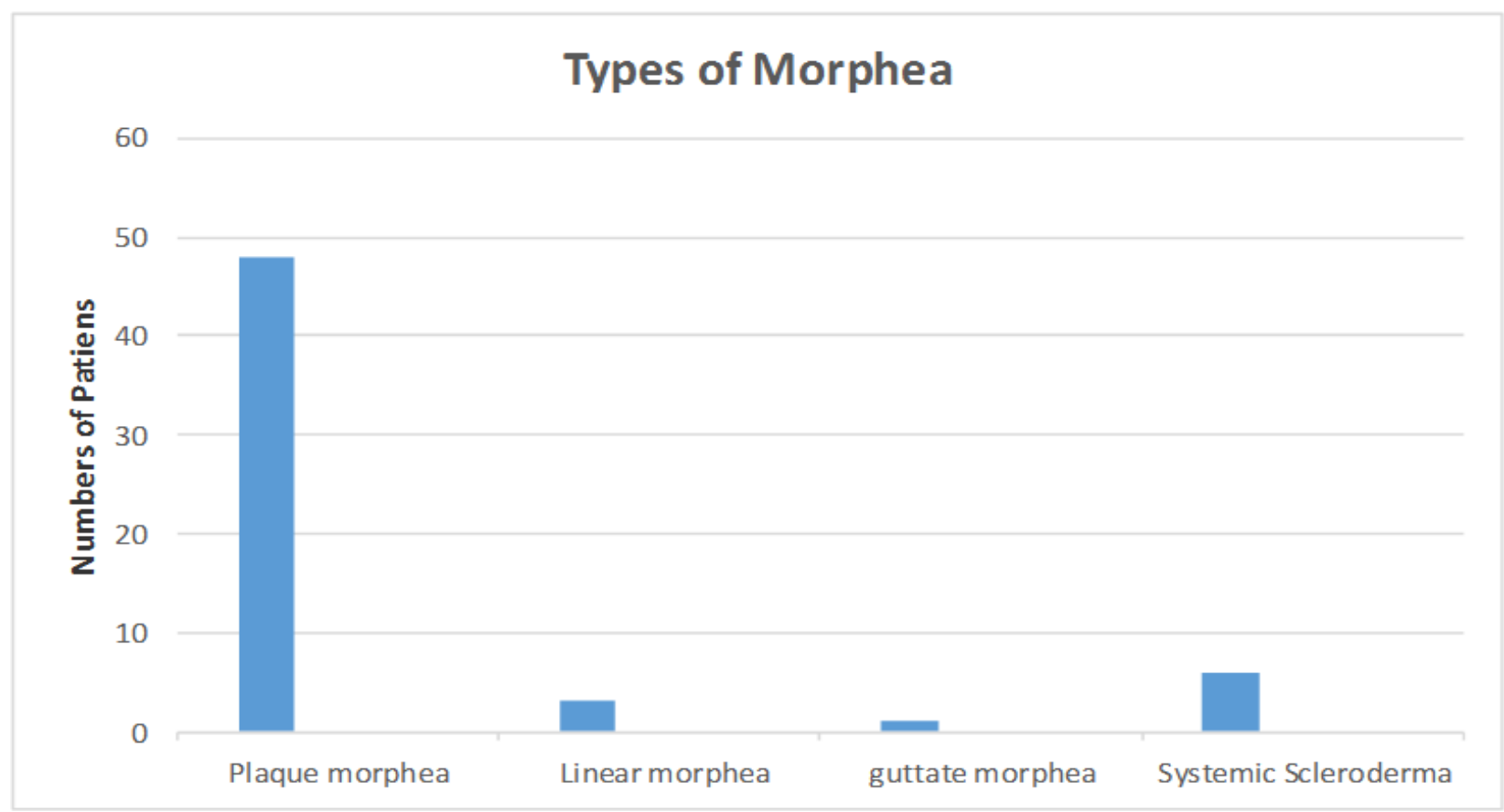

Figure 2: Types of morphea

Figure 3: Localized plaque morphea

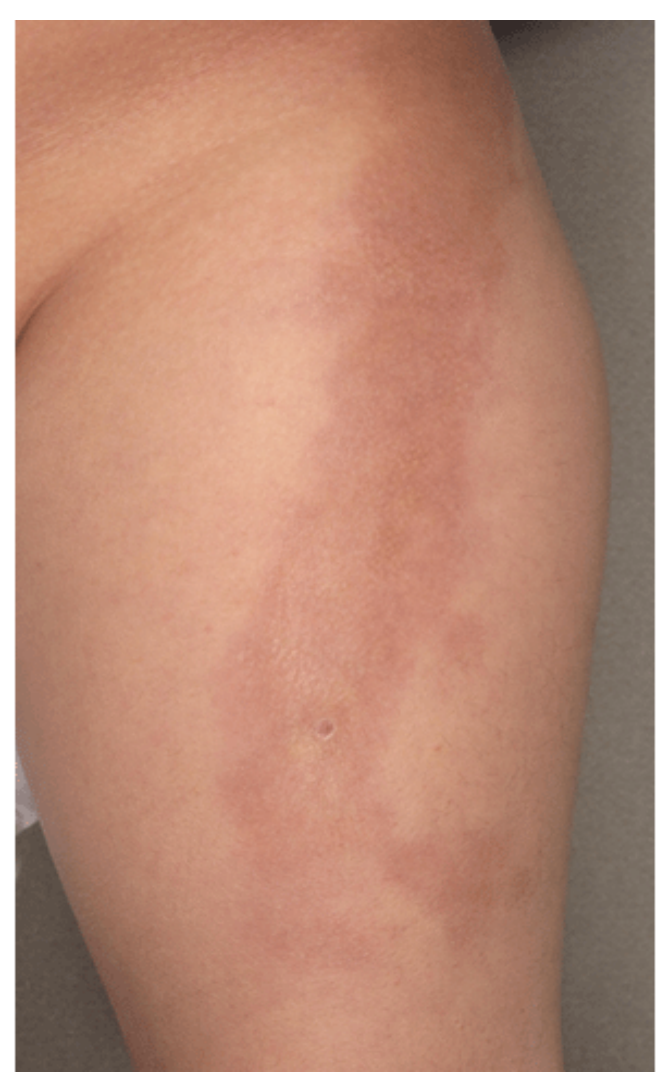

Figure 4: Linear morphea involving the left thigh 


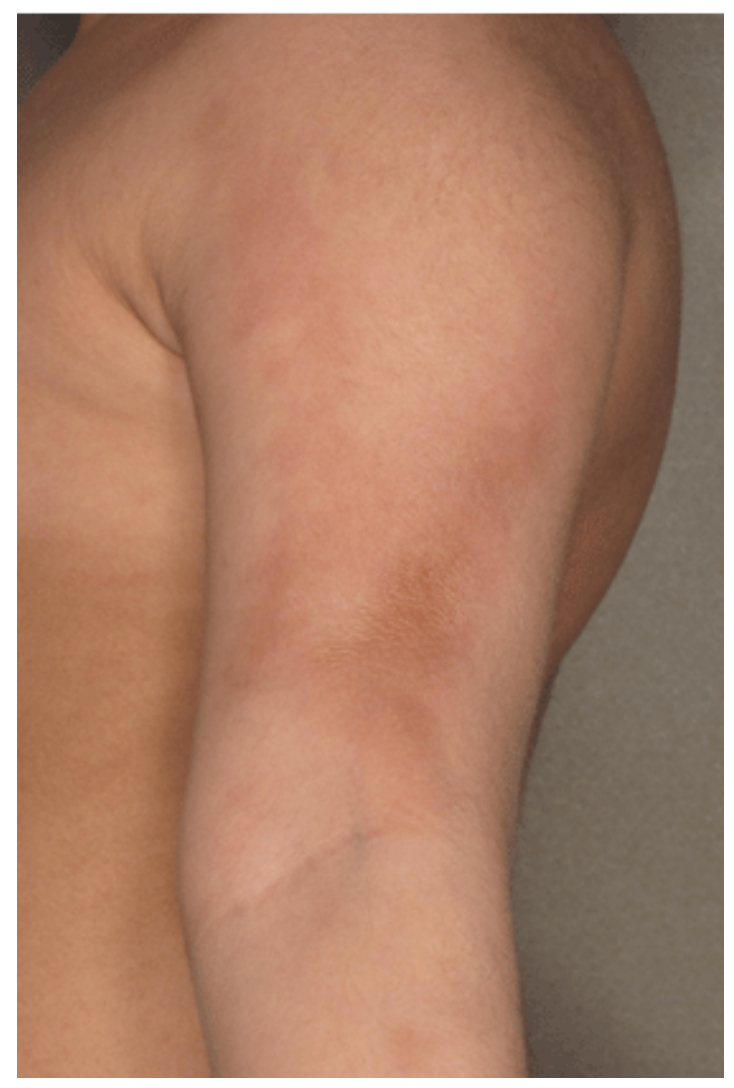

Figure 5: Plaque morphea in a 7-year-old child

\section{Discussion}

Scleroderma is a group of diseases in which there is deposition of collagen in the skin and sometimes other organs as well. When the disease limited to the skin and subcutaneous tissue, the term "morphea "is used. Morphea can also affect rarely the underlying fascia, muscles and bones. The presence of Raynaud's phenomenon and involvement of internal organs like lung and gastrointestinal tract allows separation of systemic sclerosis from morphea [1]. In small percentage of patients, skin sclerosis may lead to significant contractures or growth retardation, handicapping the affected individual for life, thus, prompt treatment is indicated [2].

Overproduction of collagen, particularly types I and III collagen, by fibroblasts in affected tissues is common to all forms of morphea. Three components are involved in the pathogenesis of morphea/scleroderma: vascular damage, lymphocyte activation, and altered connective tissue production. It has been proposed that endothelial cell damage may represent the initial step in morphea and systemic sclerosis. Early lesions are characterized by the influx of large amounts of mononuclear lymphocytes (usually activated T lymphocytes), histiocytes, eosinophils and plasma cells. There is inflammatory reaction in morphea patients (elevated ANAs, cytokines, and adhesion molecules). These cytokines (especially IL-4) upregulate transforming growth factor- $\beta$ (TGF- $\beta$ ), initiating a cascade of events resulting in increased production of collagen and other extracellular matrix components via induction of connective tissue growth factor, platelet-derived growth factor, and matrix metalloproteinases $[3,4]$.

Estimated incidence of morphea range from 0.5 to 2.7 per 100,000 with a female: male ratio of 2-3:1. In our study, the ratio was 1.5:1. The disease affects all ages; nonetheless, the peak incidence is seen between the ages of 20 and 40 years. Almost similar result was observed in Saudi Arabia. $20-30 \%$ of morphea begins in childhood.

The frequency of the different types varies between studies. This is possibly due to use of different classification systems. In our study, we used Laxer and Zulian's classification. One study revealed $56 \%$ of patients had plaque-type, $20 \%$ linear, $13 \%$ generalized, and $11 \%$ deep morphea. The most common pediatric subtype is linear morphea then En coup de sabre. In adults, circumscribed and generalized subtypes predominate. Deep morphea/morphea profunda is uncommon in both adults and children. The plaques of morphea most commonly develop on the trunk and are between 2 and $15 \mathrm{~cm}$ in diameter [5,6]. In our cases, plaque type was noted in most of the patients $83 \%$. Linear morphea was seen in $5 \%$ while guttate type observed in one case.

The presence of ANA or antibodies to ssDNA and histones are unusual in patients with plaque-type morphea. They are more frequent in linear and generalized morphea, where ANA can be found in high titers in $40-80 \%$ of patients. About $40 \%$ of children and adolescents with morphea have elevated ANA titers [7]. In this study 26 patients were tested for ANA serology, $50 \%$ of them were positive.

The microscopic feature of morphea varies depending on the stage of the disease and the biopsy site. The peripheral border may show inflammatory cells, comprised chiefly of lymphocytes and plasma cells, located in the lower dermis and scattered in the interstitium. Initial collagen changes are seen in the lower part of the dermis and subcutaneous tissue, then later affect the whole of the dermis; they include thickened collagen bundles with diminished spaces among fibers. Morphea profunda shows thickened subcutaneous fibrous septae with mononuclear infiltrate mix with many plasma cells. Excessive sclerosis and hyalinization of connective tissue may involve the underlying fascia [8]. The histopathological features of our cases were almost similar to the previously investigated studies.

In Conclusion, Morphea is an inflammatory disease characterized by excessive dermal and subcutaneous collagen production. This is the first study investigating the clinical types of morphea in Saudi patients. 


\section{References}

1. Fitzpatrick TB, Eisen AZ, Wolff K, Freedberg IM, Austen KE. Dermatology in General Medicine. 1987:1841-1852.

2. Mayes MD. Classification and epidemiology of scleroderma. Semin Cutan Med Surg. 1998;17:22-26.

3. Leitenberger JJ, Cayce RL, Haley RW, Adams-Huet B, Bergstresser PR, Jacobe HT. Distinct autoimmune syndromes in morphea: a review of 245 adult and pediatric cases. Arch Dermatol. 2009;145(5):545-550. doi: 10.1001/archdermatol.2009.79

4. Chabaud S, Corriveau MP, Grodzicky T, Senécal JL, Chartier S, Raymond $\mathrm{Y}$, et al. Decreased secretion of MMP by non-lesional late-stage scleroderma fibroblasts after selection via activation of the apoptotic fas-pathway. J Cell Physiol. 2011;226(7):1907-1914. doi: 10.1002/ jcp. 22520
5. Peterson LS, Nelson AM, Su WP, Mason T, O’Fallon WM, Gabriel SE. The epidemiology of morphea (localized scleroderma) in Olmsted County 1960-1993. J Rheumatol. 1997;24(1):73-80.

6. Fett N, Werth VP. Update on morphea: part I. Epidemiology, clinical presentation, and pathogenesis. J Am Acad Dermatol. 2011;64(2):217228; quiz 229-30. doi: 10.1016/j.jaad.2010.05.045

7. Zulian F, Vallongo C, Woo P, Russo P, Ruperto N, Harper J, et al. Localized scleroderma in childhood is not just a skin disease. Arthritis Rheum. 2005;52(9):2873-2881.

8. Lowell AG, Stephen IK, Barbara AG, Amy SP, David JL, Wolff K. Morphea. In Stephanie SD, Heidi TJ, editor. Fitzpatrick's dermatology in general medicine. 8th ed. New York: McGraw Hill; 2011. 692. 